Aim of the study: The aim of the study was to investigate whether there are differences in the various dimensions of the health locus of control between oncological and non-oncological patients and to determine whether there is a relationship between the level of health locus of control and the type, duration of disease and gender.

Material and methods: The study was conducted at the Department of Hematology and the $1^{\text {st }}$ Department of Cardiology of the University Hospital in Krakow. 204 patients were enrolled. Our own questionnaire developed for this purpose and the Multidimensional Health Locus of Control scale were used. The US normalization group and the Polish standardization groups of the chronically ill patients were used for comparative analysis.

Results: Analysis showed significant differences between women and men in the Internal control scale $(p<0.02)$. The respondents from both groups showed lower scores in the Internal locus of control and much higher scores in the dimension Powerful Others. In the group of oncological patients, a negative correlation was found between the Internal scale of health locus of control and the duration of the disease $(p=0.007)$. There was a significant difference between oncological and non-oncological patients in the Powerful Others scale $(p<0.004)$.

Conclusions: The results suggest that oncologically ill patients could be more convinced that others are responsible for their health when compared to non-oncological patients. The longer the disease persists in oncological patients, the weaker is their internal motivation to achieve good treatment results.

Key words: cancer patients, chronic disorders, health locus of control, psycho-oncology.

Contemp Oncol (Pozn) 2019; 23 (2): 115-120 DOI: https://doi.org/10.5114/wo.2019.85638

\section{Comparison of health locus of control in oncological and non-oncological patients}

\author{
Katarzyna Gibek ${ }^{1}$, Tomasz Sacha ${ }^{2}$
}

${ }^{1}$ Jagiellonian University Medical College, Krakow, Poland

${ }^{2}$ Chair and Clinic of Hematology, Jagiellonian University Medical College, Krakow, Poland

\section{Introduction}

The locus of control (LOC) is an important feature that regulates the functioning of people in a difficult situation, such as chronic illness. The concept of LOC derives from the theory of social learning by Rotter [1] and concerns beliefs about the source of health control [1, 2]. Less than 20 years after the release of Rotter's "Social learning and clinical psychology", Lavenson slightly modified and developed further this theory [3]. Finally, two types of LOC were distinguished in relation to the health condition: the internal LOC, which is an expression of the individual's conviction about its direct impact on health, and external - when the person is convinced that their health condition depends on external factors. These may include luck, chance, fate, or the influence of other people [2-5]. People with an internal LOC are characterized by greater self-activity; they control their lives and important events themselves. They believe that the probability of success depends on their own efforts, work and personal influence. They stand out with their high aspirations and faith in their own strengths. Individuals with an external LOC believe that their lives are controlled by factors independent of their conscious, intentional and deliberate influence, such as fate, destiny, God, ignorance, disease, happiness, etc. In the face of illness, they submit to medical institutions and health care workers. They do not trust themselves and do not believe in the effectiveness of their own actions [5, 6].

Wortman and Dunkel-Schetter suggest that chronically ill patients who have an internal LOC may feel frustrated and helpless due to the inability to make a significant change in their health. On the other hand, people with an external LOC may be in a better mental condition because they do not try to control their environment and therefore do not experience a high level of frustration [7]. There are studies that indicate that the health locus of control (HLC) is linked to chronic diseases [8-11].

Cancer is a chronic and often incurable disease that patients have little control over. Moreover, many patients receive chemotherapy and/or radiotherapy, which may cause a number of adverse reactions [12]. People struggling with chronic illness, in the face of long-term treatment, may perceive their health differently.

The results of Polish research on the HLC in chronically ill patients indicate significant differences in the results compared to the American standardization group in all dimensions of the HLC. Polish patients with chronic illnesses are characterized by higher scores in all dimensions of the Multidimensional Health Locus of Control (MHLC) scales [13, 14]; however no studies have been performed comparing the HLC in patients with cancer and in patients with other chronic diseases.

The aim of the study was to determine whether chronically ill patients not suffering from oncological disease differ from patients with chronic oncological disorder in individual dimensions of the MHLC, whether there is a relationship between the level of the HLC and gender, and whether the du- 
ration of the disease plays a significant role in the results obtained in both investigated groups of patients.

\section{Material and methods}

As an example of chronic oncological disease 103 patients applying to the Outpatient Hematology Department of the University Hospital in Krakow suffering from leukemia, lymphoma or multiple myeloma were enrolled in the study. The second group consisted of 101 patients with chronic cardiovascular diseases treated on an outpatient basis at the $1^{\text {st }}$ Department of Cardiology, Interventional Electrocardiology and Arterial Hypertension. The study was carried out in the period from 11.2017 to 01.2018. All investigated patients agreed to participate in the study and signed an informed consent form. The inclusion criteria for the oncological and non-oncological group were as follows: treatment due to oncological disease or cardiovascular disease

Table 1. Types and incidences of chronic diseases in the studied groups $^{*}(N=204)$

\begin{tabular}{lccc} 
Illness & Occurrence & \multicolumn{3}{c}{ Duration (in years) } \\
& $n(\%)$ & M & SD \\
Hypertension & $84(41.2)$ & 12.57 & 7.208 \\
\hline Oncological disease & $103(51.5)$ & 7.45 & 3.574 \\
Thyroid disease & $20(9.8)$ & 10.95 & 5.846 \\
\hline Heart disease & $32(15.7)$ & 11.78 & 6.657 \\
\hline Eye disease & $10(4.9)$ & 16.30 & 10.152 \\
Diabetes & $15(7.4)$ & 13.07 & 6.312 \\
$\begin{array}{l}\text { Disease of bones } \\
\text { or vertebral spine }\end{array}$ & $24(11.76)$ & 19.88 & 7.891 \\
\hline \begin{tabular}{l} 
Other \\
\hline
\end{tabular} & $19(9.31)$ & 8.89 & 3.879 \\
\hline
\end{tabular}

$M$ - mean, SD - standard deviation, * in both groups, the patients mentioned a few chronic diseases in the survey

Table 2. Comparison of the average results of the Multidimensional Health Locus of Control scale obtained by the surveyed groups

\begin{tabular}{|c|c|c|c|c|}
\hline $\begin{array}{l}\text { Health locus } \\
\text { of control }\end{array}$ & $\begin{array}{l}\text { Oncological } \\
\text { patients } \\
\begin{array}{c}n=103 \\
M \pm S D\end{array}\end{array}$ & $\begin{array}{l}\text { Non-oncological } \\
\text { patients } \\
\begin{array}{c}n=101 \\
M \pm S D\end{array}\end{array}$ & $t$ & $p$-value \\
\hline Internal & $24.92 \pm 5.61$ & $24.61 \pm 4.96$ & 0.416 & 0.678 \\
\hline $\begin{array}{l}\text { Powerful } \\
\text { Others }\end{array}$ & $28.59 \pm 4.76$ & $26.38 \pm 6.05$ & $2.909^{\star \star}$ & 0.004 \\
\hline Chance & $22.92 \pm 5.67$ & $21.71 \pm 5.57$ & 1.535 & 0.126 \\
\hline
\end{tabular}

Table 3. Average normalization indices of the health locus of control in chronically ill patients - American standards [19] and our own norms

\begin{tabular}{|c|c|c|}
\hline $\begin{array}{l}\text { Health locus } \\
\text { of control }\end{array}$ & $\begin{array}{l}\text { American standards } \\
\qquad n=609^{\star} \\
M\end{array}$ & $\begin{array}{c}\text { Own norms } \\
n=101^{* *} \\
M\end{array}$ \\
\hline Internal & 25.78 & 24.95 \\
\hline Powerful Others & 22.54 & 25.36 \\
\hline Chance & 17.64 & 21.22 \\
\hline
\end{tabular}

for a minimum of 6 months, age over 18 years and good general condition assessed according to the Eastern Cooperative Oncology Group performance scale (ECOG 1 or 2).

Research tools included: a questionnaire developed for the needs of the survey and the MHLC scale questionnaire in version B by Kenneth A. Wallston, Barbara S. Wallston, Robert DeVellis, in the adaptation of Zygfryd Juczynski.

Our own developed questionnaire included:

- sociodemographic questions about age, education and place of residence,

- questions related to the disease and treatment; name of the disease, other comorbidities; duration of treatment.

The MHLC scale questionnaire - contains 18 statements regarding general expectations in three dimensions of the HLC: Internal (W), Powerful Others (I) and Chance (P). All statements are presented on a six-point scale and include possible answers with the score: no, I strongly disagree - 1 point, to some extent I disagree - 2 points, to a small degree I disagree - 3 points, to a small extent I agree 4 points, to some extent I agree - 5 points, yes, I definitely agree -6 points. The range of results is from 6 to 36 points. A higher score means a stronger belief about the influence of a given factor on health [15].

The American standards and our own norms for chronically ill patients were used to compare the results. Our norms were created based on Polish standards [15].

The data were prepared using the IBM SPSS Statistics statistical program in version 24. Descriptive statistics (arithmetic mean [M] and standard deviation [SD]) were used, linear regression analysis and parametric tests: Student's t-test and Pearson's correlation ( $r$ ), which was used in the analysis of the relationship between the duration of disease and the level of HLC. The level of significance was $p<0.05$. Verification of normality of the distribution was performed by the Kolmogorov-Smirnov test, where the distribution was considered as "normal" at $p>0.05$.

\section{Results}

The analysis included 204 questionnaires, filled in by 101 patients suffering from oncological disease and 103 non-oncological patients. The mean age of the respondents in the oncology group was $58.8 \pm 13.44$ years and $55.44 \pm 13.55$ years in the group of the remaining patients. The average duration of oncological illness was 7 years and 5 months \pm 3.57 years, and of non-oncological chronic disease was 13 years and 6 months \pm 9.7 years. The types and incidences of chronic diseases in both groups are presented in Table 1.

In the group of oncological patients $(n=103)$, in 16 patients (15.53\%), apart from oncological disease, one of the above-mentioned chronic diseases was present, in 9 people (8.74\%) two other chronic diseases occurred, and in 6 patients $(5,83 \%)$, the three diseases mentioned above. In the non-oncological group of patients $(n=101)$, 48 (47.52\%) suffered from the two diseases listed above, 22 patients (21.78\%) from 3 diseases and 6 people (5.94\%) from four.

Comparative results of the MHLC scale revealed a statistically significant difference between the groups in the dimension Powerful Others $(t=2.91, p<0.004)$. The respondents 
from both groups obtained lower scores in the dimension of the Internal LOC and much higher scores in the dimensions Powerful Others and Chance (Table 2) in comparison to the American standardization group (Table 3).

Table 3 presents American standards published in the book Measuring Tools in Promotion and Psychology of Health and our own norms created for the needs of this study.

In the group of oncological patients, the analysis showed a negative correlation between the Internal dimension of HLC and the duration of the disease $(r=-0.265$, $p=0.007$ ). In the group of non-oncologically ill patients, a positive correlation between the duration of disease and the dimension Powerful Others was found $(r=0.239$, $p=0.016)$. The results are presented in Table 4.

Tables $4 a$ and $4 b$ show a linear regression analysis - influence of variables: sex, age, duration of disease, place of residence, occurrence (or not) of oncological disease on dependent variables - individual MHLC factors.

Table 4. Pearson's correlation coefficient $(r)$ between the MHLC scale dimensions and the duration of the disease

\begin{tabular}{|c|c|c|c|c|}
\hline \multirow[t]{2}{*}{$\begin{array}{l}\text { Health locus } \\
\text { of control }\end{array}$} & \multicolumn{2}{|c|}{$\begin{array}{c}\text { Oncological patients } \\
\qquad n=103\end{array}$} & \multicolumn{2}{|c|}{$\begin{array}{l}\text { Non-oncological patients } \\
\qquad n=101\end{array}$} \\
\hline & $r$ & $p$-value & $r$ & $p$-value \\
\hline Internal & $-0.265^{\star *}$ & 0.007 & 0.043 & 0.667 \\
\hline Powerful Others & 0.001 & 0.990 & $0.239^{*}$ & 0.016 \\
\hline Chance & 0.013 & 0.900 & 0.145 & 0.147 \\
\hline
\end{tabular}

Table 4a. Variable - Internal locus of the control

\begin{tabular}{|c|c|c|c|c|c|}
\hline \multirow[t]{2}{*}{ Predictors } & \multicolumn{2}{|c|}{$\begin{array}{l}\text { Unstandardized } \\
\text { coefficients }\end{array}$} & \multirow{2}{*}{$\begin{array}{c}\text { Standardized } \\
\text { coefficients } \\
\beta\end{array}$} & \multirow[t]{2}{*}{$t$} & \multirow[t]{2}{*}{$p$-value } \\
\hline & B & Std. error & & & \\
\hline Constant & 28.110 & 1.880 & & & 0.000 \\
\hline $\begin{array}{l}\text { Oncological/ } \\
\text { Non- } \\
\text { oncological ill }\end{array}$ & 0.009 & 0.763 & 0.001 & 0.012 & 0.990 \\
\hline Age & -0.037 & 0.028 & -0.093 & -1.301 & 0.195 \\
\hline $\begin{array}{l}\text { Duration } \\
\text { of disease }\end{array}$ & -0.050 & 0.044 & -0.084 & -1.140 & 0.255 \\
\hline Sex & -1.559 & 0.745 & -0.148 & $-2.091^{*}$ & 0.038 \\
\hline
\end{tabular}

Table 4b. Variable - Powerful Others

\begin{tabular}{|c|c|c|c|c|c|}
\hline Predictors & $\begin{array}{c}\text { Unstan } \\
\text { coeff } \\
\text { B }\end{array}$ & $\begin{array}{l}\text { Idardized } \\
\text { ficients } \\
\text { Std. error }\end{array}$ & $\begin{array}{c}\text { Standardized } \\
\text { coefficients } \\
\beta\end{array}$ & $t$ & $p$-value \\
\hline (Constant) & 27.247 & 1.967 & & & 0.000 \\
\hline $\begin{array}{l}\text { Oncological/ } \\
\text { Non- } \\
\text { oncologically ill }\end{array}$ & -2.658 & 0.785 & -0.241 & $-3.388^{\star \star}$ & 0.001 \\
\hline Age & 0.065 & 0.029 & 0.158 & $2.265^{\star}$ & 0.025 \\
\hline $\begin{array}{l}\text { Duration } \\
\text { of disease }\end{array}$ & 0.078 & 0.045 & 0.126 & 1.753 & 0.081 \\
\hline Sex & -0.952 & 0.775 & -0.086 & -1.229 & 0.221 \\
\hline $\begin{array}{l}\text { Place } \\
\text { of residence }\end{array}$ & 0.427 & 0.823 & 0.036 & 0.519 & 0.604 \\
\hline
\end{tabular}

The analysis showed a significant impact of the gender variable on the level of the Internal LOC $(p=0.038)$. Women, compared to men, have a lower Internal LOC by 1.6 points. The result has been standardized into variables entered in the model.

The analysis showed a significant effect of age on the level of the variable Powerful Others ( $p=0.025$ ). A year older people achieved about 0.065 more points on this scale. The analysis also showed the influence of the oncological and non-oncological disease variable on the results of Powerful Others $(p=0.001)$. Non-oncologically ill patients have a 2.7 points lower level of the LOC in the factor Powerful Others. The result was standardized for the remaining variables.

No statistically significant differences were found in the model for the Chance variable.

Differences in individual parameters of the HLC between women and men in all patients are listed in Table 2. A joint analysis of patients from both groups indicates statistically significant differences between women and men in Internal control - internal LOC $(t=2.29, p<0.02)$. In

Table 5. Health locus of control in all respondents in relation to gender (Student's t-test)

\begin{tabular}{lcccc} 
Health locus & \multicolumn{5}{c}{ Both groups together } \\
\cline { 2 - 5 } of control & $\begin{array}{c}\text { Women } \\
n=106\end{array}$ & $\begin{array}{c}\text { Men } \\
n=98\end{array}$ & $t$ & $p$-value \\
& $M \pm S D$ & $M \pm S D$ & & \\
& $23.96 \pm 5.56$ & $25.64 \pm 4.86$ & $2.291^{*}$ & 0.023 \\
\hline Internal & $27.14 \pm 5.72$ & $27.88 \pm 5.34$ & 0.948 & 0.344 \\
\hline $\begin{array}{l}\text { Powerful } \\
\text { Others }\end{array}$ & & & & \\
\hline Chance & $23.04 \pm 5.96$ & $21.55 \pm 5.21$ & -1.892 & 0.060
\end{tabular}

$M$ - mean; SD - standard deviation; $t$-Student's t-test result, ${ }^{*} p<0.05$, ${ }^{* *} p<0.01$

Table 5a. Health locus of control in relation to gender in the group of non-oncological patients (Student's $t$-test)

\begin{tabular}{lcccc} 
Health locus & \multicolumn{5}{c}{ Non-oncological patients } \\
\cline { 2 - 5 } of control & $\begin{array}{c}\text { Women } \\
n=106 \\
\mathrm{M} \pm \mathrm{SD}\end{array}$ & $\begin{array}{c}\text { Men } \\
\mathbf{M}=98\end{array}$ & $t$ & $p$-value \\
& $23.85 \pm 4.90$ & $25.49 \pm 4.93$ & 1.670 & 0.098 \\
\hline Internal & $25.39 \pm 6.45$ & $27.51 \pm 5.40$ & 1.777 & 0.079 \\
\hline $\begin{array}{l}\text { Powerful } \\
\text { Others }\end{array}$ & & & & \\
\hline Chance & $21.67 \pm 6.08$ & $21.77 \pm 4.99$ & 0.089 & 0.928
\end{tabular}

Table $5 \mathrm{~b}$. Health locus of control in relation to gender in the group of oncological patients (Student's t-test)

\begin{tabular}{|c|c|c|c|c|}
\hline \multirow{2}{*}{$\begin{array}{l}\text { Health locus } \\
\text { of control }\end{array}$} & \multicolumn{4}{|c|}{ Oncological patients } \\
\hline & $\begin{array}{l}\text { Women } \\
n=52 \\
M \pm S D\end{array}$ & $\begin{array}{c}\text { Men } \\
n=51 \\
M \pm S D\end{array}$ & $t$ & $p$-value \\
\hline Internal & $24.08 \pm 6.22$ & $25.78 \pm 4.83$ & 1.554 & 0.123 \\
\hline $\begin{array}{l}\text { Powerful } \\
\text { Others }\end{array}$ & $28.96 \pm 4.18$ & $28.22 \pm 5.41$ & -0.793 & 0.430 \\
\hline Chance & $24.46 \pm 5.53$ & $21.35 \pm 5.44$ & $-2.876^{\star \star}$ & 0.005 \\
\hline
\end{tabular}


other dimensions, no statistically significant differences were found between men and women.

Tables $5 \mathrm{a}$ and $5 \mathrm{~b}$ presents differences in the HLC according to gender separately for both investigated groups of patients. In the group of oncological patients there were statistically significant differences in the external HLC located in the Chance scale $(t=-2.88, p<0.004)$ in relation to gender (Table $5 b$ ). Statistically significant differences occurred between oncological and non-oncological women in the Chance scale $(t=2.47, p<0.015)$ and Powerful Others $(t=3.37, p<0.001)$. The separate analysis of both groups did not show a significant difference in men in the factor Internal LOC. No statistically significant differences were found in the other factors.

\section{Discussion}

The aim of the study was to determine and to compare the HLC among oncological and non-oncological patients and to understand differences between the groups. For the comparison of the internal and external HLC, a confirmed MHLC scale was used in both groups. The MHLC scale has been used for several years in many studies concerning oncological patients $[13,16,17]$ and chronically ill patients without cancer $[14,18]$. The HLC is an important factor in determining how the patient deals with the disease, treatment and rehabilitation.

The standards for the investigations of chronically ill patients in the USA were created on the basis of studies carried out in the years 1978-1979 [19]. Therefore it was decided to compare the results of the present research with the average results of the American standardization group and additionally with our own norms based on Polish research carried out in the years 1998-1999 by Juczynski, performed on several groups of patients representing various disease entities [15]. Juczynski published Polish standards for the MHLC tool in his book "Measuring Tools in Promotion and Psychology of Health" [15]. These norms were established for several different chronically ill patient groups: undergoing dialysis, diabetics patients, men after myocardial infarction, women with complicated pregnancy, women during menopause, and women after mastectomy. Of all of these groups, only the dialysis $(n=31)$ and diabetics $(n=70)$ patients were included in our own norms of chronically ill patients. The other groups were rejected because they presented norms only for one of the sexes. From the obtained results of the two groups, the average for each of the dimensions was calculated.

Studies that assessed separately the HLC in oncologically and chronically non-oncologically ill patients could be found in available literature; however, there is a lack of studies presenting a direct comparison of both groups.

The literature on research on the HLC indicates the internal LOC as a factor facilitating the actions taken to prevent health problems and avoiding health-threatening behaviors [17]. It is believed that people with a higher level of Internal LOC may be in better health than people who, in the assessment of this factor, achieve a lower level [20]. In the present study, it was found that patients with chronic diseases in both groups obtained lower results (oncological $-M=24.92$, $S D=5.61$, non-oncological $-M=24.61$,
$\mathrm{SD}=4.96)$ on the Internal LOC scale in comparison to the American standardization group $(M=25.78)$ and comparable to our own created norms $(M=24.95)$. With regard to American norms [15], chronically ill patients from our study group had a lower level of Internal LOC. They may think that they have little influence on their own life and health situation, may not undertake pro-health activities, and not seek to improve health to the same extent as people with a higher level of Internal LOC. The results obtained in this study may suggest that when compared to our own norms the patients believe that they have a moderate impact on their own health situation, and they approach them with detachment from pro-health activities.

The present results are different from the results of Kurpas et al. [14] and from some of the results of Kosowicz et al. [13]. In the research of Kurpas, the HLC factors were examined in people with chronic disorders, including those with chronic cardiovascular and nervous system diseases and with diabetes. The subject of Kosowicz's research was "The health locus of control, anxiety and depression in patients with soft tissue and bone cancer", in which the patients treated for the first time and once again were subjected to the tests. In the reported studies, patients with chronic illness (Kurpas) and cancer patients (Kosowicz) had higher scores on the Internal LOC scale compared to both groups of oncological and non-oncological patients in our study, except for patients with nervous system diseases [14] and patients with cancer treated for the first time [13], where the results were significantly lower $(M=23.50$, $\mathrm{SD}=5.78)$. It is worth noting that in the studies of Kosowicz, the studied group of patients consisted of 40 cancer patients, including 22 patients treated for the first time and 18 patients treated once more, and in the present study a total of 204 patients were examined, including 103 oncologically ill patients, which could at least partially explain the differences in the obtained results. Another differentiating factor may be the duration of the disease and the phase of treatment in which they are. Patients treated for cancer for the first time have a much weaker belief that they can decide about their health condition themselves, they do not know what to expect and they are burdened with enormous stress. The patient who receives the second cycle of treatment is already richer with this knowledge and experience from the first stage of treatment [21]. The type of cancer, the method of treatment and inclusion of a group of people with cancer recurrence could probably also influence the variety of results.

Patients with high scores on the Internal LOC scale exhibit the most pro-healthy behaviors compared to other patients. In the present study, both groups were characterized by slightly lower results on this scale and much higher on the other scales when compared to our own norms. Such results may suggest that the patients from the studied group are weekly motivated to fight the disease by themselves, their actions are characterized by significant passivity and they place faith in external actions that are to lead to cure. Their rehabilitation and therapy process may be significantly longer than those with different results and more disruptive for themselves.

The regression analysis showed that women compared to men have a lower Internal LOC by 1.6 points $(p=0.038)$. How- 
ever, the comparison of the results of this variable in both groups separately showed a significant difference only in the Chance factor. In the oncological group, women had significantly higher scores than men. Sherman and others analyzed a lot of research on differences in individual LOC parameters in women and men, where different variables, such as mental health condition, social efficacy or stress, are also affected by the results on individual scales [22]. Therefore, in order to better refer to the obtained results, not only gender but also other factors should be taken into account in future studies.

Research by Burish et al. suggested that the external LOC may be beneficial in helping cancer patients to adapt to their chronic disease [23]. Patients in both groups showed much higher scores on the Powerful Others scale compared to the American normalization group ( $M=$ 22.54) and slightly higher when compared to their own normalization group $(M=25.36)$. The study also revealed a significant difference between the two groups $(t=2.909$, $p<0.01$ ) in this dimension (Table 4). The group of oncological patients obtained similar results to the group of patients with diabetes $(M=28.08, S D=6.46)$ in the study of Kurpas [14] and to the group of patients with cancer treated once again $(M=28.11, S D=5.17)$ in the study of Kosowicz [13]. Similarly, in other studies oncological patients had higher scores on the scale of the external LOC compared to the control group of healthy people [24, 25].

According to Levenson, patients with high scores on the Powerful Others scale may have more problems with effective coping with illness and react negatively to rehabilitation [26]. These patients may be convinced that others, for example health care workers, are responsible for their health, the therapy process and rehabilitation. This can reduce the consistency of complying with medical advice, including following prescriptions, and can negatively affect the regularity or examinations as well as doctor's appointments [27].

The analysis performed in our studied group showed that non-oncological patients in comparison to oncological patients have 2.7 points lower level of control in the discussed factor. These results seem to confirm the observation made by Levenson. Wallston and Wallston also suggested that in situations where only low internal control is possible, as in patients with cancer, patients are dependent more on external sources of control, such as doctors or others (e.g. family), than on internal ones [28].

There were no significant differences between oncological and non-oncological groups in the Chance factor. Patients with an elevated score on this scale may believe that their lives and health are determined by their fate or chance [29]. In both studied groups the sores were higher (oncological: $M=22.92$, non-oncological: $M=21.71$ ) than in the American normalization group $(M=17.64)$ and comparable to our own norms $(M=21.22)$. In the studies of Kosowicz [13] and Kurpas [14] in all the studied groups, much higher results were obtained when compared to both normalization groups (own group and an American group) and slightly higher compared to those obtained in the present study.

The study showed that in the group of oncological patients, the longer the duration of the disease was, the lower are the obtained results in terms of the Internal LOC $(r=-0.265, p=0.007)$. This could suggest that the longer the respondents get sick, the weaker is their internal motivation and the belief that they contribute to achievement of good treatment results. Their sense of responsibility for the treatment process could be decreased, and they are not willing to take pro-health measures. As the other research results show, the duration of the disease may affect the mental condition of patients; the longer the chronic illness lasts, the worse are the quality of life and the mental condition [30]. In the group of patients with non-oncological chronic disease, prolonged duration of the disease correlated with higher results obtained in Powerful Others $(r=0.239$, $p=0.016)$. This suggests that the longer patients get sick, the more they perceive their own health as a result of other "external" activities, such as health care and medical personnel. With the duration of the disease, the deteriorating mental condition of patients may cause patients to trust others more in the treatment process. It was suspected that in each of the groups the duration of the disease would correlate with all of the above dimensions; however, the correlations appeared only in one of the three expected factors.

It should be taken into account that the above analyses on the MHLC scale and other Polish studies mentioned above were compared with the normalization group of patients chronically ill from the USA [15]. People who are healing and suffering in another country may differ in many respects: cultural, social, property and other. The healthcare system, and access to medicines and specialists are completely different in the United States than in Poland. There is a lack of reliable standardization group of patients suffering from chronic illnesses described in the Polish literature.

Therefore a clinical investigation aiming at development of a reliable Polish standardization group of chronically ill patients should be planned.

The standards for the investigations of chronically ill patients in the USA were created on the basis of studies carried out in the years 1978-1979 [19]. Therefore it was decided to compare the results of the present research with the average results of the American standardization group and additionally with our own norms based on Polish research carried out in the years 1998-1999 by Zygfryd Juczynski, performed on several groups of patients representing various disease entities [15]. Juczynski published Polish standards for the MHLC tool in his book "Measuring Tools in Promotion and Psychology of Health" [15]. These norms have been established for several different chronically ill patient groups: undergoing dialysis, diabetics patients, men after myocardial infarction, women with complicated pregnancy, women during menopause, and women after mastectomy. Of all of these groups, only the dialysis $(n=31)$ and diabetics $(n=70)$ patients were included in our own norms of chronically ill patients. The other groups were rejected because they presented norms only for one of the sexes. From the obtained results of the two groups, the average for each of the dimensions was calculated.

There are many interpretations in the literature of individual factors influencing the LOC and many questions regarding the validity of the MHLC scale have been raised [31, 32]. The relationship between individual dimensions and health outcomes is very complicated as described in the literature review published in 2007 [33]. Given the above, one should be cautious about the conclusions of the studies in which the MHLC scale is used. Therefore fu- 
ture investigations should incorporate and analyze a wide range of variables in addition to MHLC to elucidate further and describe more precisely the relations between patient-related individual factors of the HLC.

\section{Conclusions}

The current study may suggest that oncologically ill patients could be more convinced that others are responsible for their health compared to non-oncological patients.

Oncologically ill men believe more in their own strength than women from the same group. Women show stronger belief than men about the impact of the accident on their health.

The results may suggest that the longer the disease persists in oncological patients, the weaker is their internal motivation to achieve results in treatment, and their sense of responsibility for the process weakens. In the case of non-oncological patients, the longer they get sick, the more they perceive their own health as a result of the actions of other people.

Both groups tested showed higher scores at all scales in comparison with the American standardization group and comparable to our own standardization group created for this study.

To properly compare each of the dimensions of the MHLC scale for chronically ill patients, it would be recommended to create a large Polish standardization group.

\section{The authors declare no conflict of interest.}

\section{References}

1. Rotter JB. Social learning and clinical psychology. Prentice Hall, Englewood Cliffs, New Jersey 1954.

2. Rotter JB. Generalized expectancies for internal versus external control of reinforcement. Psychol Monogr 1966; 80: 1-28.

3. Heszen I, Sek H. Psychologia zdrowia. PWN, Warszawa 2007.

4. Sęk H. Psychologia kliniczna Tom 1. PWN, Warszawa 2008.

5. Sęk H. Psychologia kliniczna Tom 2. PWN, Warszawa 2008.

6. Drwal RL Poczucie kontroli jako wymiar osobowości - podstawy teoretyczne, techniki badawcze i wyniki badań. In: Adaptacja kwestionariuszy osobowości. Wybrane zagadnienia i techniki, Drwal RL (ed.). PWN, Warszawa 1995; 199-227.

7. Wortman CB, Dunke-Schetter C. Interpersonal Relationships and Cancer: A Theoretical Analysis. J Soc Issues 1979; 35: 120-155.

8. Gale CR, Batty GD, Deary IJ. Locus of control at age 10 years and health outcomes and behaviors at age 30 years: the 1970 British Cohort Study. Psychosom Med 2008; 70: 397-403.

9. Neylon A, Canniffe C, Anand S, et al. A Global perspective on psychosocial risk factors for cardiovascular disease. Prog Cardiovasc Dis 2013; 55: 574-581.

10. Henninger DE, Whitson HE, Cohen HJ, Ariely D. Higher medical morbidity burden is associated with external locus of control. J Am Geriatr Soc 2012; 60: 751-755.

11. Sturmer T, Hasselbach P, Amelang M. Personality, lifestyle, and risk of cardiovascular disease and cancer: follow-up of population based cohort. BMJ 2006; 332: 1359.

12. de Walden-Gałuszko K. Wybrane zagadnienia psychoonkologii i psychotanatologii. Psychologiczne aspekty choroby nowotworowej, umierania i śmierci. Wyd. Uniwersytetu Gdańskiego, Gdańsk 1992; 8-62.

13. Kosowicz M, Kulpa M. i inni. Umiejscowienie kontroli zdrowia a lęk i depresja u pacjentów z chorobą nowotworową tkanek miękkich i kości. Med Paliat 2014; 6: 165-169.

14. Kurpas D, Kusz J. Jedynak T, Mroczek B. Umiejscowienie kontroli zdrowia u osób ze schorzeniami przewlekłymi. Fam Med Primary Care Rev 2012: 14: 186-188.
15. Juczyński Z. Narzędzia pomiaru w promocji zdrowia. Pracownia Testów Psychologicznych Polskiego Towarzystwa Psychologicznego, Warszawa 2009

16. Rowe JL, Montgomery GH, Duberstein PR, Bovbjerg DH. Health locus of control and perceived risk for breast cancer in healthy women. Behav Med 2005; 31: 33-40.

17. Marijanovic I, Pavlekovic G, Buhovac T, Martinac M. The relationship between health locus of control, depression, and sociodemographic factors and amount of time breast cancer patients wait before seeking diagnosis and treatment. Psychiatr Danub 2017; 29: 330-344.

18. Sak J, Jarosz MJ, Mosiewicz J, Sagan D, Wiechetek M, Pawlikowski J, Włoszczak-Szubzda A, Olszewska E. Postrzeganie własnej choroby a poczucie odpowiedzialności za swoje zdrowie osób przewlekle chorych. Med Og Nauk Zdr 2011; 17; 169-173.

19. Wallston KA, Wallston BS. Health locus of controls scale. In: Research with the locus of control construct, Lefcourt HM (ed.) Academic Press, New York 1981; 189-243.

20. Lefcourt HM, Davidson-Katz K. Locus of control and health. In: Handbook of Social and Clinical Psychology: the health perspective, Snyder CR, Forsyth DR (eds.). Pergamon Press, New York 1991; 246-266.

21. Little M, Jordens CFC, Paul K, Montgomery K, Philipson B. Liminality: a major category of the experience of cancer illness. Soc Sci Med 1998; 47: 1485-1494.

22. Wessels H, de Graeff A, Wynia K, de Heus M, Kruitwagen CL, Woltjer GT, Teunissen SC, Voest EE. Gender-related needs and preferences in cancer care indicate the need for an individualized approach to cancer patients. Oncologist 2010; 15: 648-655.

23. Burish TG, Carey MP, Wallston KA, Stein MJ, Jamison RN, Lyles JN. Health locus of control and chronic disease: An external orientation may be advantageous. I Soc Clin Psychol 1984; 2: 326-332.

24. Jamison RN, Lewis S, Burish TG. Psychological impact of cancer on ad olescents: self-image, locus of control, perception of illness and knowledge of cancer. J Chronic Dis 1986; 39: 609-617.

25. Kellerman J, Zeltzer L, Ellenberg L, Dash J, Rigler D. Psychological effects of illness in adolescence: Anxiety, self-esteem and perception of control. J Pediatr 1980; 97: 126-131.

26. Marshall GN. A multidimensional analysis of internal health locus of control beliefs: separating the wheat from the chaff. J Pers Soc Psychol 1991; 61: 483-491.

27. Levenson $H$. Differentiating among internality, powerful others, and chance. In: Research with the locus of control construct, Lefcourt HM (ed.). Academic Press, New York 1981; 15-63.

28. Wallston BD, Wallston KA. Locus of control and health: a review of the literature. Health Education Monograph 1978; 6: 107-117.

29. Juczyński Z. Psychologiczne wyznaczniki zachowań zdrowotnych na przykładzie badań osób dorosłych. In: Ku lepszemu funkcjonowaniu w zdrowiu i chorobie, Łazowski Ł, Dolińska-Zygmunt G (ed.). AWF, Wrocław 1997; 285-291.

30. Żołnierczuk-Kieliszek D, Kulik TB, Maciejasz AE, Kawiak-Jawor E, Janiszewska M, Stefanowicz A. Wybrane czynniki psychologiczne i medyczne a jakość życia chorych na choroby układu krążenia. Med Ogólna Nauki Zdr 2014; 20: 131-135.

31. Marshall GN. A multidimensional analysis of internal health locus of control beliefs: separating the wheat from the chaff? J Pers Soc Psychol 1991; 61: 483-491

32. Anderson LA, DeVellis RF, Sharpe PA, Marcoux B. Multidimensional Health Locus of Control scales: do they measure expectancies about control or desires for control? Health Educ Res 1994; 9: 145-151.

33. Neipp M-C, López-Roig S, Pastor MA. Control beliefs in cancer: A literature review. Anu Psicol 2007; 38: 333-355.

\section{Address for correspondence}

\section{Katarzyna Gibek}

Jagiellonian University Medical College

12 św. Anny St.

31-008 Krakow, Poland

e-mail: k.gibek@doctoral.uj.edu.pl

Submitted: 31.01 .2019

Accepted: 15.04 .2019 